Article

\title{
Comparison of Energy Used and Effects on Bulk Density and Yield by Tillage Systems in a Semiarid Condition of Mexico
}

\author{
Alfredo López-Vázquez ${ }^{1}$, Martin Cadena-Zapata ${ }^{2, *}$, Santos Campos-Magaña ${ }^{2}$, \\ Alejandro Zermeño-Gonzalez ${ }^{3}$ and Mario Mendez-Dorado ${ }^{2}$ \\ 1 Production Systems Engineering Program, Universidad Autónoma Agraria Antonio Narro, \\ Calzada Antonio Narro 1923 Saltillo, Coahuila 25315, Mexico; fred.max@live.com.mx \\ 2 Agricultural Machinery Department UAAAN Saltillo, Universidad Autonoma Agraria Antonio Narro, \\ Saltillo, Coahuila 25315, Mexico; camposmsg@hotmail.com (S.C.-M.); \\ mario.mendez@uaaan.edu.mx (M.M.-D.) \\ 3 Irrigation and Drainage Department UAAAN, Saltillo, Universidad Autonoma Agraria Antonio Narro, \\ Saltillo, Coahuila 25315, Mexico; azermeno@uaaan.mx \\ * Correspondence: martin.cadena@uaaan.edu.mx; Tel.: +52-844-534-2349
}

Received: 19 February 2019; Accepted: 12 April 2019; Published: 13 April 2019

\begin{abstract}
Energy used for tillage is an input with a high impact on the cost of crop production; it is desirable to till the soil using minimum energy. The objective of this study was to compare the specific energy expenditure, effect on soil bulk density, and forage yield of maize, by three tillage systems: Disk plow/Disk Harrow/planter (DDP), Chisel plow/Disk harrow/planter (CHDP) and No-Tillage (NT). Energy was measured for tillage operations in the summer season of 2013, 2016, and 2017. Bulk density in 2013 and 2016. Yield in 2013 and 2014. The variables of drawbar force (kN), working speed $\left(\mathrm{m} \mathrm{s}^{-1}\right)$, width $(\mathrm{m})$, depth $(\mathrm{m})$, fuel consumption $\left(\mathrm{L} \mathrm{ha}^{-1}\right)$, bulk density $\left(\mathrm{g} \mathrm{cm}^{-3}\right)$, and dry matter yield $\left(\mathrm{Mg} \mathrm{ha}^{-1}\right)$ were measured. Results showed that there were significant differences in the amount of energy used per ha; DDP used an average of 379.75 MJ, CHDP 135.01 MJ, and NT 26.43 MJ. The average energy applied to the soil mass for each system was $400 \mathrm{~J} \mathrm{~kg}^{-1}$ for DDP, $255.13 \mathrm{~J} \mathrm{~kg}^{-1}$ for CHDP, and for NT was $237.8 \mathrm{~J} \mathrm{~kg}^{-1}$. The overall energy efficiency was; $18.23 \%$ for DDP, $6.88 \%$ for CHDP, and $4.77 \%$ for N. The bulk density decreased significantly after three years for NT. There were no significant differences in dry matter yield. In the semiarid condition of Mexico, CHDP and NT are options for saving from $64 \%$ to $93 \%$ of energy, compared with DDP.
\end{abstract}

Keywords: energy; tillage systems; fuel consumption; energy use efficiency; semiarid condition

\section{Introduction}

Soil tillage requires high energy input, normally diesel fuel [1-3]. In these times, it is necessary to make the most efficient use of all inputs, to have a sustainable crop production system [4].

Conventional tillage (DDP) implies a working depth from $0.25 \mathrm{~m}$ to $0.30 \mathrm{~m}$ for disk plowing with an intensive manipulation of a high volume of soil; thus requiring from five to nine times more energy compared with conservation tillage [5]. This intensive tillage can also lead to the degradation of soil structure, increasing the bulk density, and, thereby, affect porosity, hydraulic conductivity, and other soil properties that are important for the availability of water for crops [6].

Chisel Tillage (CHDP) avoids these drawbacks in two ways; it does not invert the soil, thus, preserving the soil structure, while leaving crop residues on the surface, which helps prevent water loss by evaporation. [7]. This type of conservation tillage decreases the intensity and frequency of soil disturbance, compared with conventional tillage [8]. No-Tillage (NT), by direct planting into 
unprepared soil, causes the least disturbance to the soil. Direct seed planters cause a minimum of soil disturbance [9]. However, impacts of tillage systems on soil properties and yields are variable and are highly dependent on site conditions, such as soil type, climate, and production systems [10].

The cost of energy for tillage activities is increasing. International prices of diesel fuel rose 3.2 times in a period of nine years from 2004 to 2013 [11]. In Mexico, the prices of fuels derived from petroleum increased 2.3 times in the decade from 2007 to 2017 [12]. In field studies, it has been determined that up to $42 \%$ of energy for crop production is from the use of diesel [13].

With the continuous increase in prices for fossil fuels, producers look for options to diminish the amount of energy applied to food production systems [14]. The possibility of reducing production costs through the efficient use of energy is the main reason many farmers adopt conservation tillage systems, rather than a desire to preserve natural resources [15].

However, the use of energy should not be analyzed only from an economic point of view. It is important to consider that fossil fuels are being depleted and that their use is causing environmental problems [16]. Therefore, the use of tillage practices should be oriented not only to reducing energy expenditure but also to conserving natural resources [17]. The reduction of energy in tillage operations is one of the characteristics of conservation tillage systems. For example, [18] documented a decrease in the use of energy from $31 \%$ to $40 \%$ in conservation systems compared with a conventional production system of maize and wheat.

Management strategies, such as crop rotation and reduction of tillage practices, can improve efficiency in energy use [19]. Other studies show that from $10 \%$ to $30 \%$ of the applied energy for crop production could be saved by adopting best calibration and maintenance practices, as well as training operators [20].

Studies which simulate the variables that influence field fuel consumption for tractors have been conducted in an effort to find better use of energy. This allows growers to implement management strategies to maximize the performance and efficiency of field operations [21,22]. However, soil and climate conditions vary widely. Most studies of tillage methods have been conducted in temperate and humid climates. So, these results are not necessarily appropriate for the arid and semiarid climates $[23,24]$.

The Northeast of Mexico is a semiarid region, cropland amounts 2.7 million ha. The main crops are forages (oats, alfalfa, maize) grain sorghum, grain maize, soybean, cotton, and pecan trees [25]. Conservation of water may be the most critical issue in the region. Soil erosion driven by wind and water is also a concern [26]. Policymakers and farmers need technical information to take appropriate soil management decisions to enhance soil quality and yields [27].

In some conditions, conservation tillage, (reduced tillage, vertical tillage, and no tillage), improves physical and biological soil properties [28]. Reducing tillage and maintaining crop residues on the soil surface can improve water use efficiency [29], aggregate stability, water infiltration and availability, and improve with conservation tillage systems, compared to conventional tillage [30]. In other cases, no tillage results in negative effects, increasing the bulk density in the surface, lowering the infiltration rates, and decreasing crop yield, compared with conventional tillage [31,32].

It is necessary to assess the performance under differing conditions, analyzing the efficiency of energy use and productivity, to have the criteria to determine the best methods and technologies [33].

The objective of this study was to compare energy usage, the effect on soil bulk density and crop yield among three tillage methods: DDP, CHDP, and NT. Specifically, we determined the energy per worked area $\left(\mathrm{MJ} \mathrm{ha}{ }^{-1}\right)$, the energy used for moving the soil mass $\left(\mathrm{J} \mathrm{kg}^{-1}\right)$, the overall efficiency, the bulk density, and yield for the three methods. It was expected that in the semiarid condition of Mexico, the conservation tillage systems, CHDP and NT, would demand less fuel and energy, have a positive effect on bulk density and yield as compared with the conventional system (DDP), most commonly used in our area. 


\section{Materials and Methods}

\subsection{Study Site}

Field experiments were conducted in the summer crop seasons of 2013, 2016, and 2017 at the experimental station of Universidad Autonoma Agraria Antonio Narro in Saltillo, Coahuila, Mexico. The site is located at $25^{\circ} 23^{\prime} 42^{\prime \prime} \mathrm{N}$ and $100^{\circ} 59^{\prime} 57^{\prime \prime} \mathrm{W}$, at an altitude of $1743 \mathrm{~m}$ above sea level. The climate is semiarid with an average annual temperature of $16.9^{\circ} \mathrm{C}$, the mean annual rainfall $435 \mathrm{~mm}$, and annual evaporation of $1956 \mathrm{~mm}$.

The soil is a clay loam (34.1\% clay, 33.4\% silt, and $32.5 \%$ sand) with $2.09 \%$ of organic matter. Average soil bulk density for the site is $1.37 \mathrm{gr} \mathrm{cm}^{-3}$. At each season just before the tillage operations, samples of soil were taken at each plot with an auger, weighed, and oven dry for $24 \mathrm{~h}$ at $105^{\circ} \mathrm{C}$ and the moisture content calculated on weight basis. Average soil moisture content is presented in Table 1.

Table 1. Average soil moisture content in the soil profile $(30 \mathrm{~cm})$ at the experimental plots.

\begin{tabular}{cccc}
\hline \multirow{2}{*}{ Tillage Systems } & \multicolumn{3}{c}{ Years } \\
\cline { 2 - 4 } & $\mathbf{2 0 1 3}$ & $\mathbf{2 0 1 6}$ & $\mathbf{2 0 1 7}$ \\
\hline & & Soil moisture content w/w \\
DDP & 11.20 & 11.73 & 5.32 \\
CHDP & 10.54 & 15.33 & 7.09 \\
NT & - & 8.89 & 6.62 \\
\hline
\end{tabular}

Tillage systems: Disk plow/Disk Harrow/Planter (DDP), Chisel plow/Disk harrow/Planter (CHDP) and No-Tillage (NT).

\subsection{Treatments and Experimental Setup}

The three tillage treatments were applied in plots of $12 \mathrm{~m} \times 40 \mathrm{~m}$ and replicated three times. A description of the characteristics of the implements is presented in Table 2.

Table 2. Characteristics of the implements used for the tillage systems.

\begin{tabular}{ccccc}
\hline Characteristics & $\begin{array}{c}\text { Disk Plow } \\
\text { ARHK-3 }\end{array}$ & $\begin{array}{c}\text { Chisel Plow } \\
\text { JD 610 }\end{array}$ & $\begin{array}{c}\text { Offset Disk Harrow } \\
\text { RI 2024 }\end{array}$ & $\begin{array}{c}\text { Planter } \\
\text { JD Max Emerge }\end{array}$ \\
\hline Working tools & $\begin{array}{c}\text { 3 discs of 711 mm } \\
\text { diameter and 6.35 } \\
\text { mm thickness, Disk } \\
\text { concavity 110 mm }\end{array}$ & $\begin{array}{c}\text { 8 tines “C” type } \\
\text { shank }\end{array}$ & $\begin{array}{c}\text { Front section of 10 notched disks, one rear } \\
\text { section of 10 plain disks with a disk spacing } \\
\text { of 230 mm, diameter of disk of 609.6 mm } \\
\text { and 4 mm thickness. Disk concavity 95 mm }\end{array}$ & $\begin{array}{c}\text { 4 planting units at } \\
\text { spacing of } 910 \mathrm{~mm}, \\
\text { double disk opener }\end{array}$ \\
\hline $\begin{array}{c}\text { Weight of } \\
\text { implement }(\mathrm{kg})\end{array}$ & 542 & 618 & 674 \\
\hline $\begin{array}{c}\text { Type of coupling to } \\
\text { the tractor }\end{array}$ & \multicolumn{2}{c}{ Mounted, three-point linkage category 2 } \\
\hline
\end{tabular}

The operations for the Disk Plow Tillage (DDP) were: Disk plowing (disk plow ARHK-3, Kimball, Torreon, COAH. Mexico), harrowing (disk harrow RI 20204, Tecnomec Agricola SA de CV, AGS. Mexico), and planting (planter JD Max Emerge 7000, John Deere SA de CV, Monterrey, NL, Mexico).

For Chisel Plow Tillage (CHDP), the operations were: Chisel plowing (Chisel plow JD610, John Deere SA de CV Monterrey, NL, Mexico), Disk harrowing, and planting.

For No-Tillage (NT), the only tillage operation was planting.

The collection of data in the field was made under a fully randomized experimental design. For the statistical analysis of the data we used R software. For the comparison of mean values, between treatments, we used the Tukey test with $\alpha \leq 0.05$.

\subsection{Measurement of Variables in the Field}

The following variables were measured during the soil preparation of the summer cropping season in 2013, 2016, and 2017. 
The net force (NF) required for pulling the implements used in the tillage systems was measured using an integrated dynamometer for mounted tillage implements. The dynamometer consists of three octagonal extended ring (OER) transducers and a floating structure attached to the three-point linkage of the tractor [34]. The implements were coupled to the dynamometer as shown in Figure 1. The power source was a John Deere tractor model 6403, 2WD with a rated engine power of $73 \mathrm{~kW}$. The front to rear weight distribution is $35 \%$ and $65 \%$.

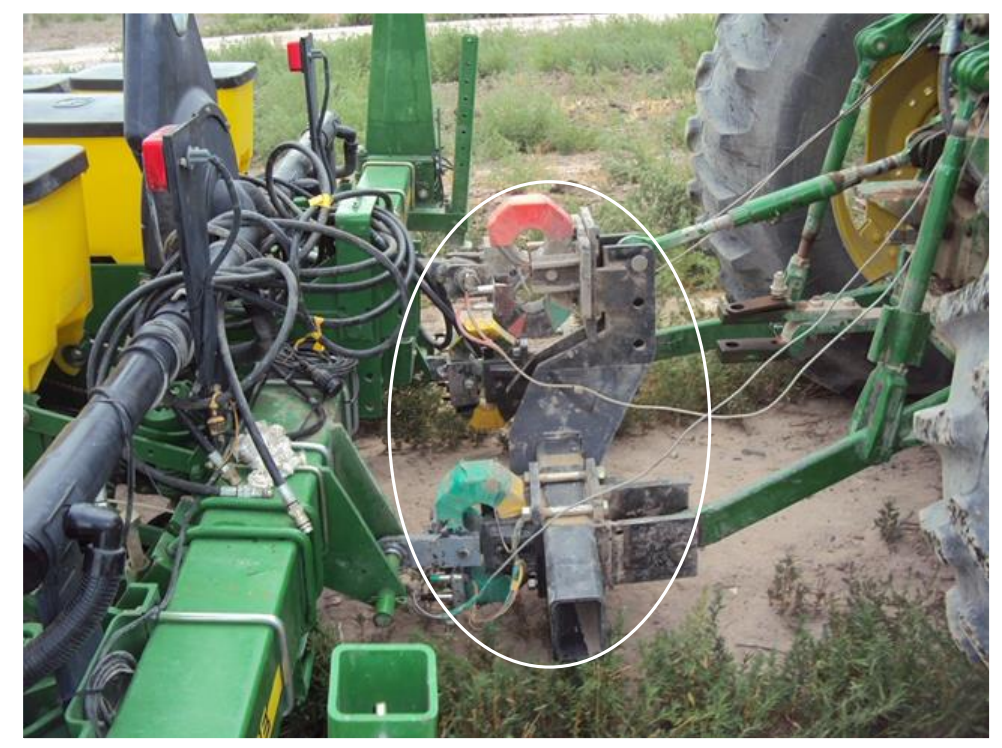

Figure 1. An integrated dynamometer for mounted implements (circled) attached to the three-point linkage. The implements are coupled to the dynamometer.

A converter Daq Book 2000 (IOtech, MCC Corporation, Norton, MA, USA) was used to register and transform the signals from the dynamometer at a sampling speed of $20 \mathrm{~Hz}$ and pass them to a DBK-43A (IOtech) signal conditioner and store the data in a PC on board in the tractor.

Fuel consumption was measured with a flowmeter S-004 BAICO (BAICO, Guadalajara, Jal, Mexico). This has two sensors; one measures the input flow to the engine and the other measures the return flow to the fuel tank. The sensors send the signals to a data logger Log Book 360 (IOtech). The net consumption is calculated by the difference between the input and return pulses, and this is multiplied by a calibration constant (3.09) to obtain the net volume consumption. The fuel consumption was referenced to the worked area to obtain $\mathrm{L} \mathrm{ha}^{-1}$.

When performing each tillage operation, working speed $\left(\mathrm{m} \mathrm{s}^{-1}\right)$ was measured in three replications per plot, by recording the time that the tractor took to travel $20 \mathrm{~m}$. In the field, working width $(\mathrm{m})$ and working depth $(\mathrm{m})$ were measured using metric tape, stainless steel ruler, and hand level. Average of the three replications for working width, and five replications for working depth, were computed for each plot. Table 3 presents the average values of these variables.

Table 3. Average of the data measured for working speed, width, and depth.

\begin{tabular}{ccccc}
\hline $\begin{array}{c}\text { Average of Field } \\
\text { Measurements }\end{array}$ & $\begin{array}{c}\text { Disc Plow } \\
\text { ARHK-3 }\end{array}$ & $\begin{array}{c}\text { Chisel Plow } \\
\text { JD 610 }\end{array}$ & $\begin{array}{c}\text { Disc Harrow } \\
\text { RI 2024 }\end{array}$ & $\begin{array}{c}\text { Planter } \\
\text { JD Max Emerge }\end{array}$ \\
\hline Working width $(\mathrm{mm})$ & 800 & 2200 & 2250 & 2700 \\
Working speed $\left(\mathrm{m} \mathrm{s}^{-1}\right)$ & 1.11 & 1.10 & 1.24 & 1.27 \\
Working depth $(\mathrm{mm})$ & 237 & 166 & 126.5 & 50 \\
\hline
\end{tabular}

\subsection{Calculation of Energy}

The net power (NP) required for each tillage operation was calculated according to Equation (1), by multiplying the net force $(\mathrm{kN})$ to pull the implement, by the working speed $\left(\mathrm{m} \mathrm{s}^{-1}\right)$, obtaining 
the net power in units of $\mathrm{kW}$; this also can be expressed in units of energy per time $\left(\mathrm{kJ} \mathrm{s}^{-1}\right)$, as in Equation (2).

$$
\mathrm{NP}=\mathrm{F} \times \mathrm{V}
$$

where: $\mathrm{NP}=$ net power $(\mathrm{kW}) ; \mathrm{NF}=$ net force $(\mathrm{kN}) ; \mathrm{V}=$ working speed $\left(\mathrm{ms}^{-1}\right)$.

This can be expressed as:

$$
\mathrm{Et}=\mathrm{E} / \mathrm{t}
$$

where $\mathrm{Et}=$ net energy applied per time during the tillage operation $\left(\mathrm{kJ} \mathrm{s}^{-1}\right) ; \mathrm{E}=$ net energy $(\mathrm{kN} \times \mathrm{m})=\mathrm{kJ}$; $\mathrm{t}=$ time (s).

The calculation of the net energy per hectare $\left(\mathrm{MJ} \mathrm{ha}^{-1}\right)$ was made by dividing the energy applied per time for each operation $\left(\mathrm{kJ} \mathrm{s}^{-1}\right)$, by the net field work capacity of each tillage operation, as in Equation (4). The net field capacity was calculated, as in Equation (3), from the field data of working speed $\left(\mathrm{km} \mathrm{h}^{-1}\right)$ and working width $(\mathrm{m})$ for each tillage operation.

$$
\mathrm{NFC}=\mathrm{W} \times \mathrm{V} / 10
$$

where NFc $=$ Net field work capacity $\left(\right.$ ha $\left.\mathrm{h}^{-1}\right) ; \mathrm{W}=$ working width $(\mathrm{m}) ; \mathrm{V}=$ working speed $\left(\mathrm{km} \mathrm{h}^{-1}\right)$.

$$
\mathrm{NE}=\mathrm{Et} / \mathrm{NFc}
$$

where $\mathrm{NE}=$ net energy applied per ha $\left(\mathrm{MJ} \mathrm{ha}^{-1}\right) ; \mathrm{Et}=$ energy applied per time during the tillage operation $\left(\mathrm{MJ} \mathrm{h}^{-1}\right) ; \mathrm{NFc}=$ net field work capacity $\left(\right.$ ha $\left.\mathrm{h}^{-1}\right)$.

The calculation of the energy applied to the soil mass $\left(\mathrm{J} \mathrm{kg}^{-1}\right)$ was computed using Equation (5).

$$
\mathrm{Esm}=\mathrm{Et} /(\mathrm{Sm})
$$

where: Esm = energy applied to the soil mass $\left(\mathrm{J} \mathrm{kg}^{-1}\right) ; \mathrm{Et}=$ energy applied per time during the tillage operation $\left(\mathrm{J} \mathrm{s}^{-1}\right)$; $\mathrm{Sm}=$ weight of soil being moved per time during the tillage labor $\left(\mathrm{kg} \mathrm{s}^{-1}\right)$.

The energy applied per time is calculated from the net force to pull the implement $(\mathrm{N})$ multiplied by the working speed $\left(\mathrm{ms}^{-1}\right)$.

The weight of the soil being moved per time is calculated as follows:

$$
\mathrm{Sm}=\mathrm{W} \times \mathrm{D} \times \mathrm{V} \times \mathrm{Bd}
$$

where: $\mathrm{Sm}=$ soil moved per time $\left(\mathrm{kg} \mathrm{s}^{-1}\right) ; \mathrm{W}=$ working width $(\mathrm{m}) ; \mathrm{D}=$ working depth $(\mathrm{m}) ; \mathrm{V}=$ working speed $\left(\mathrm{m} \mathrm{s}^{-1}\right)$; $\mathrm{Bd}=$ Bulk density of the soil $\left(\mathrm{kg} \mathrm{m}^{-3}\right)$.

\subsection{Calculation of Overall Efficiency}

The overall efficiency of the use of fuel by the tillage system that includes the load matching of the tractor and implement, the tractive efficiency, and the engine/power train operating conditions was obtained using Equation (7), by dividing the net energy used for the tillage operation in a hectare and the energy produced by the net volume of fuel used per hectare, similar to that proposed by [35].

$$
\mathrm{OE}=(\mathrm{NE} /(\mathrm{HHVD} \times \mathrm{NFC})) \times 100)
$$

where $\mathrm{OE}=$ Overall efficiency of the use of fuel $(\%) ; \mathrm{NE}=$ Net energy applied per ha $\left(\mathrm{MJ} \mathrm{ha}^{-1}\right)$; HHVD $=$ Higher heating value of diesel fuel $=38.59 \mathrm{MJ} \mathrm{L}^{-1} ; \mathrm{NFC}=$ Net fuel consumption $\left(\mathrm{L} \mathrm{ha}^{-1}\right)$.

\subsection{Bulk Density and Total Porosity}

At the end of the summer cropping season 2013, and after three years in 2016, at each tillage treatment, undisturbed core samples were carefully taken in the soil profile from 0 to $20 \mathrm{~cm}$ at intervals 
of $5 \mathrm{~cm}$. The core sampling was made using cylinders of $50 \mathrm{~mm}$ diameter and $50 \mathrm{~mm}$ length; samples were processed according to procedures described in [36]. Soil bulk density was calculated as follows:

$$
\mathrm{Bd}=\mathrm{M} / \mathrm{V}
$$

where $\mathrm{Bd}=$ bulk density $\left(\mathrm{gr} \mathrm{cm}^{-3}\right) ; \mathrm{M}=$ mass of the dry soil sample $(\mathrm{gr}) ; \mathrm{V}=$ volume of sample $\left(\mathrm{cm}^{3}\right)$.

Total porosity was calculated from the values of bulk density and particle density. The later was determined by the picnometry method [37]. Total porosity was calculated as follows:

$$
\mathrm{TP}=(1-\mathrm{Bd} / \mathrm{Pd}) \times 100
$$

where $\mathrm{TP}=$ total porosity $(\%) ; \mathrm{Bd}=$ bulk density $\left(\mathrm{gr} \mathrm{cm}^{-3}\right) ; \mathrm{Pd}=$ particle density $\left(\mathrm{gr} \mathrm{cm}^{-3}\right)$.

\subsection{Crop Yield}

The crop maize was harvested in 2013 and 2014 as fodder. Following the procedure of [38], samples of the crop were cut, weighed as green fodder, and then dehydrated at a temperature of $70{ }^{\circ} \mathrm{C}$ for $72 \mathrm{~h}$ until depletion of moisture, and so, its weight was constant, to obtain the yield of the dry fodder. This was taken as the dry matter weight of the crop, to calculate yield per hectare.

\section{Results and Discussion}

\subsection{Draft and Energy for Tillage Operation and Systems}

The draft for each tillage implement is presented in Table 4 . The draft was calculated with the force measured to pull the implement and the working width. The draft ranged from a minimum of $1.81 \mathrm{kN} \mathrm{m}^{-1}$ for the planter to a maximum of $29.89 \mathrm{kN} \mathrm{m}^{-1}$ for the disk plow. Working depth was the main factor that influenced the draft. As seen in Table 5, the average working depth was disk plow > chisel plow > disk harrow $>$ planter, so in this order was the implement draft.

Table 4. Draft for each implement used in the tillage systems.

\begin{tabular}{cccccc}
\hline Implement/Year & $\mathbf{2 0 1 3}$ & $\mathbf{2 0 1 6}$ & $\mathbf{2 0 1 7}$ & Average & ASABE Estimate \\
\hline \multicolumn{5}{c}{ Draft $\left(\mathrm{kN} \mathrm{m}^{-1}\right)$} \\
\hline Disk Plow & 29.89 & 27.99 & 31.10 & 29.66 & - \\
Chisel Plow & 11.28 & 5.32 & 8.16 & 8.25 & 12.60 \\
Disk Harrow & 5.56 & 5.18 & 4.92 & 5.22 & 7.60 \\
Planter & 2.81 & 1.81 & 1.95 & 2.19 & 2.64 \\
\hline
\end{tabular}

Table 5. Working depth of the implements for each tillage system.

\begin{tabular}{lcccc}
\hline & \multicolumn{3}{c}{ Years } & Average \\
\cline { 2 - 3 } Tillage Systems & $\mathbf{2 0 1 3}$ & $\mathbf{2 0 1 6}$ & $\mathbf{2 0 1 7}$ & \\
\cline { 2 - 4 } & \multicolumn{4}{c}{ Working Depth $\mathbf{( m m )}$} \\
\hline DDP & 279 & 169 & 263 & 237 \\
Disk Plow & 100 & 130 & 148 & 126 \\
Disk Harrow & 50 & 50 & 50 & 50 \\
Planter & 148 & 119 & 231 & 166 \\
\hline CHDP & 100 & 130 & 150 & 127 \\
Chisel Plow & 50 & 50 & 50 & 50 \\
Disk Harrow & & & 50 & 50 \\
Planter & 50 & 50 & 50 \\
\hline NT & & &
\end{tabular}


The American Society of Agricultural and Biological Engineers (ASABE) Standard D497.7 [39] defines tillage implement draft as force per unit width. The average measured values of tillage implement draft were compared to those estimated with the equation $\mathrm{D}=\mathrm{Fi}\left(\mathrm{A}+\mathrm{B}(\mathrm{S})+\mathrm{C}(\mathrm{S})^{2}\right) \mathrm{WT}$, where $\mathrm{D}$ is the implement draft per unit width; $\mathrm{Fi}$ is a dimensionless soil texture adjustment parameter with different values for fine-, medium-, and coarse-textured soils; A, B, and C are machine-specific parameters; $S$ is field speed; $W$ is implement width; and $T$ is tillage depth. The equation of the ASABE Standard overestimates by $20.50 \%$ the draft for the planter, $52.66 \%$ for the Chisel plow, and $45.60 \%$ for the disk harrow. No data for disk plow or similar implement is in the ASABE Standard D497.7. The ASABE coefficients in the equation are for a wide range of soil conditions and consequently cannot be expected to result in accurate estimates for a particular situation. The standard has an expected range of $\pm 35 \%$ for the draft for direct planters, so the measured value was within this range, up to $\pm 50 \%$ for offset disk harrows, the measured value was also in the range, and up to $\pm 50 \%$ for chisel plow, so the measured value is a bit out of the range. In a similar study, the draft for the chisel plow was overestimated by the standard by $69 \%$ [40].

The average amount of energy used for each labor, with each tillage system, is observed in Table 6. In the DDP system, primary tillage with the disk plow required the greatest quantity of energy compared to all other implements. For this tillage operation, year to year variations were not significant. For the subsequent tillage operations of harrowing and planting in the conventional system, likewise, there were no significant differences in the amount of energy between years.

In relation to the CHDP system, the primary tillage made with the chisel plow had a significantly lower value of energy in 2016 compared to the other years; this decrease in energy was related to the shallower working depth (Table 6) and the relatively higher moisture content in the soil profile for that year (Table 1). For the secondary tillage operation of harrowing, there were no significant differences between years. Energy for planting in this system was significantly higher in 2013 compared to the other years.

Table 6. Specific energy per area used at each labor for the different tillage systems.

\begin{tabular}{|c|c|c|c|c|}
\hline \multirow{3}{*}{ Tillage Systems } & \multicolumn{3}{|c|}{ Years } & \multirow{2}{*}{ Average } \\
\hline & 2013 & 2016 & 2017 & \\
\hline & \multicolumn{4}{|c|}{ MJ ha ${ }^{-1}$} \\
\hline \multicolumn{5}{|l|}{ DDP } \\
\hline Disk Plow & $284.59 \mathrm{a}$ & $298.17 \mathrm{a}$ & $311.02 \mathrm{a}$ & 297.93 \\
\hline Disk Harrow & $74.02 \mathrm{a}$ & $50.55 \mathrm{a}$ & $46.56 \mathrm{a}$ & 57.04 \\
\hline Planter & $27.86 \mathrm{a}$ & $25.58 \mathrm{a}$ & 20.89 a & 24.78 \\
\hline \multicolumn{5}{|l|}{ CHDP } \\
\hline Chisel Plow & $89.02 \mathrm{a}$ & $43.56 \mathrm{~b}$ & $74.25 \mathrm{a}$ & 68.94 \\
\hline Disk Harrow & $62.63 \mathrm{a}$ & $40.25 \mathrm{a}$ & $39.60 \mathrm{a}$ & 47.49 \\
\hline Planter & 28.67 a & $13.95 \mathrm{~b}$ & $13.09 \mathrm{~b}$ & 18.57 \\
\hline \multicolumn{5}{|l|}{ NT } \\
\hline Planter & $28.05 \mathrm{ab}$ & $18.59 \mathrm{~b}$ & $32.65 \mathrm{a}$ & 26.43 \\
\hline
\end{tabular}

The no-till system had only the labor of direct planting. The lower use of energy in 2016 for this operation coincides with a relatively greater moisture content compared with 2017.

The requirement of energy for the tillage operations depends mainly on the soil resistance, which, in turn is related to moisture content, working depth, and working width. In our study, Disk plow had the highest draft force and energy requirement because of the deeper working depth. Similarly, in other studies with primary tillage using moldboard or disk plows, the demand of drawbar force, and, hence, energy, was higher compared to other implements [41-43]. 
The quantity of net energy demand, from the tillage implements in conservation systems, was lower than that for the conventional system, commonly used in the region of our study. The results were in general accord with the findings of other studies undertaken in different environmental conditions. [44,45].

In Figure 2, it is observed that the total net energy for each tillage system is significantly different. The energy used by the sequence of operations of the CHDP system saved, on average, up to $64 \%$ of energy and NT saved up to $93 \%$ of energy, compared with the DDP. These findings are similar to the results obtained by other authors studying conservation tillage [46,47].

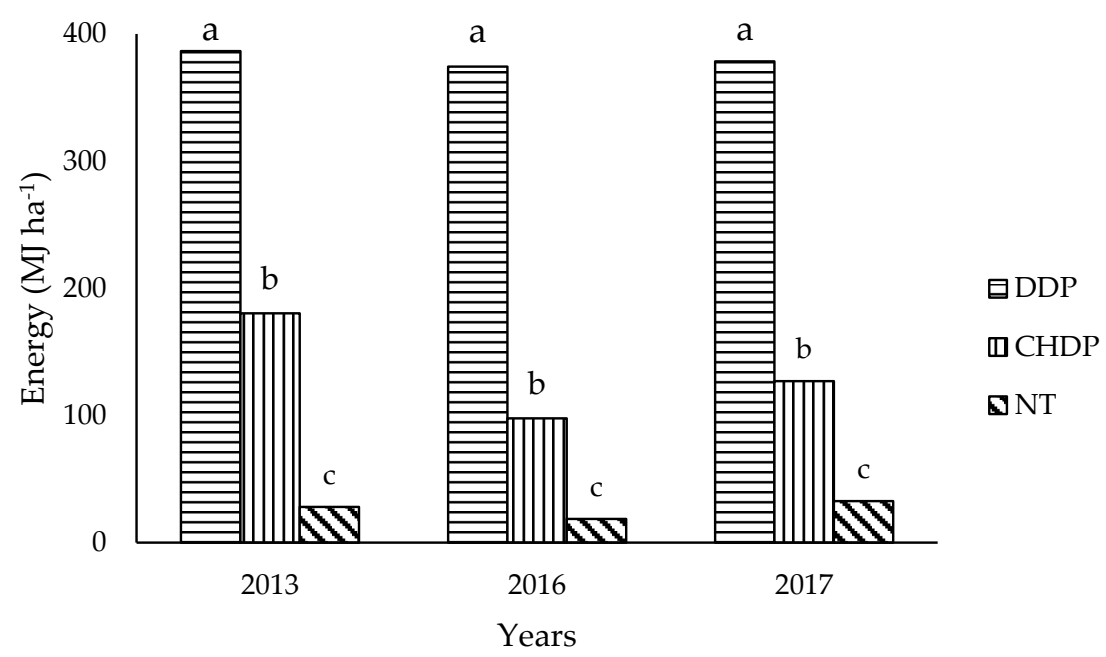

Figure 2. Energy per worked area for each tillage system; different letters in columns in the same year have significant differences (Tukey, $\alpha \leq 0.05$ ).

The amount of energy used is related to the volume of soil worked (Table 7). The DDP system moved an average of $4530 \mathrm{~m}^{-3}$ per hectare, while the CHDP system moved $15.5 \%$ less and NT system moved $80 \%$ less volume of soil, compared to the DDP system. These results show the higher demand for energy for DDP.

Table 7. Volume of soil moved for each operation in the tillage systems.

\begin{tabular}{lcccc}
\hline \multirow{2}{*}{ Tillage Systems/Years } & $\mathbf{2 0 1 3}$ & $\mathbf{2 0 1 6}$ & $\mathbf{2 0 1 7}$ & Average \\
\cline { 2 - 5 } & \multicolumn{5}{c}{ Volume of Soil Moved $\mathbf{~ m}^{\mathbf{3}} \mathbf{h a}^{\mathbf{- 1}}$} \\
\hline DDP & 2790 & 1690 & 2630 & 2370 \\
$\quad$ Disk Plow & 1000 & 1300 & 1480 & 1260 \\
$\quad$ Disk Harrow & 500 & 1100 & 1100 & 900 \\
$\quad$ Planter & 1475 & 1190 & 2310 & 1658 \\
\hline CHDP & 1000 & 1300 & 1500 & 1267 \\
$\quad$ Chisel Plow & 500 & 1100 & 1100 & 900 \\
$\quad$ Disk Harrow & & & & \\
$\quad$ Planter & 500 & 1100 & 1100 & 900 \\
\hline NT $\quad$ Planter & &
\end{tabular}

\subsection{Specific Draft per Soil Volume and Specific Energy per Moved Soil Mass}

The specific draft force per unit volume of soil disturbed for each implement at each system is shown in Table 8. It can be seen that the highest specific draft per volume is applied with the tools of the planter in contact with soil; this is because the unit of volume of soil disturbed in the planting line is the smallest compared with the other implements, thus resulting in a high energy applied to the worked soil volume. 
Table 8. Draft applied per volume of soil disturbed for each implement at each tillage system.

\begin{tabular}{lcccc}
\hline & \multicolumn{3}{c}{ Years } & \multirow{2}{*}{ Average } \\
\cline { 2 - 4 } Tillage Systems & $\mathbf{2 0 1 3}$ & $\mathbf{2 0 1 6}$ & $\mathbf{2 0 1 7}$ & \\
\cline { 2 - 4 } & \multicolumn{4}{c}{$\mathbf{k N ~ m}^{-\mathbf{3}}$} \\
\hline DDP & $115.29 \mathrm{~b}$ & $166.89 \mathrm{~b}$ & $118.52 \mathrm{~b}$ & 133.56 \\
$\quad$ Disk plow & $66.61 \mathrm{c}$ & $38.88 \mathrm{c}$ & $31.04 \mathrm{c}$ & 45.51 \\
Disk harrow & $457.74 \mathrm{a}$ & $410.17 \mathrm{a}$ & $338.74 \mathrm{a}$ & 402.21 \\
$\quad$ Planter & $92.65 \mathrm{~b}$ & $36.50 \mathrm{~b}$ & $32.02 \mathrm{~b}$ & 53.72 \\
\hline CHDP & $55.60 \mathrm{c}$ & $30.96 \mathrm{~b}$ & $26.71 \mathrm{~b}$ & 37.75 \\
$\quad$ Chisel Plow & $470.99 \mathrm{a}$ & $226.73 \mathrm{a}$ & $226.23 \mathrm{a}$ & 307.81 \\
$\quad$ Disk harrow & & & \\
$\quad$ Planter & 460.82 & 244.31 & 384.35 & 363.16 \\
\hline NT & &
\end{tabular}

Mean values with the same letter in a column in the same tillage system are not significant different (Tukey, $\alpha \leq 0.05$ ).

As the volume of worked soil increases the specific draft per volume diminish. Implements with the bigger working width, such as the chisel plow and disk harrow, applied less specific draft per volume to the soil compared to the disk plow that have less width. Similar results in tillage intensity are presented in [48], where a moldboard plow working at greater depth and less width applied a greater specific draft energy to the soil, compared to a field cultivator working at greater width and less depth.

Figure 3 presents the total specify energy applied to the soil mass by the sum of operations in each tillage system. The sum of tillage operations of DDP was the system which applied the greatest amount of energy to the soil mass to achieve the seedbed preparation. It can be noticed that NT, with only one operation of planting, exerts a great deal of energy (a high loading rate) to a small soil mass unit; it represents from $40 \%$ to $80 \%$ of that exerted for all the operations of the DDP in the different years studied. Specific energy applied to the soil mass is required to reduce the size of soil aggregates. The amount of energy depends on the stress loading rates [49]. In the NT system, it is required that the tools of the planter, in contact with the soil, leave a condition of small aggregates for an adequate soil seed contact. These tools are designed to achieve this condition with only one pass.

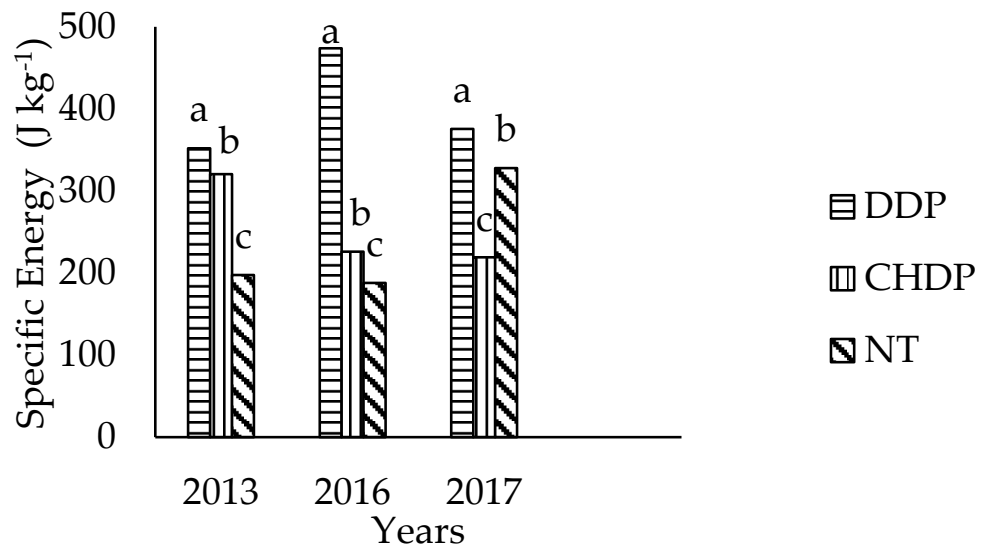

Figure 3. Specific energy applied to the soil mass for each tillage energy; different letters in columns in the same year are significantly different (Tukey, $\alpha \leq 0.05$ ).

\subsection{Fuel Used by Worked Area}

Fuel consumption was registered only for the years 2016 and 2017. 
In Table 9, the fuel consumption for each operation in the tillage systems can be seen. Disk plowing recorded the highest fuel consumption per worked area while showing the lowest fuel consumption for the planting operation.

Table 9. Fuel consumption per worked area for each operation in the tillage systems.

\begin{tabular}{lccc}
\hline & \multicolumn{2}{c}{ Years } & \multirow{2}{*}{ Average } \\
\cline { 2 - 3 } Tillage Systems & $\mathbf{2 0 1 6}$ & $\mathbf{2 0 1 7}$ & \\
\cline { 2 - 3 } & & $\mathbf{L ~ h a}^{\mathbf{- 1}}$ \\
\hline DDP & $25.35 \mathrm{a}$ & $31.36 \mathrm{a}$ & 28.35 \\
Disk plow & $14.88 \mathrm{a}$ & $12.93 \mathrm{a}$ & 13.90 \\
Disk harrow & $13.40 \mathrm{a}$ & $10.90 \mathrm{a}$ & 12.15 \\
$\quad$ Planter & & & \\
\hline CHDP & $23.73 \mathrm{a}$ & $20.68 \mathrm{a}$ & 22.20 \\
Chisel plow & $15.78 \mathrm{a}$ & $14.00 \mathrm{a}$ & 14.89 \\
Disk harrow & $9.26 \mathrm{a}$ & $9.64 \mathrm{a}$ & 9.45 \\
Planter & & & 11.07 \\
\hline NT & $11.87 \mathrm{a}$ & $10.27 \mathrm{a}$ & \\
$\quad$ Planter & &
\end{tabular}

Mean values with the same letter in the same row are not significantly different (Tukey, $\alpha \leq 0.05$ ).

The sequence of operations of DDP had the greatest fuel consumption. This is similar to other studies where the highest fuel consumption was logged by a conventional system of deep plowing, compared to a reduced tillage system, which required up to 58\% less fuel [50]. Increase in fuel consumption is generally related to increase in working depth. Consequently, disk plowing had the greatest fuel consumption, followed by chisel plowing, disk harrowing, and planting.

Figure 4, shows the fuel consumption per area for each tillage system. In the year 2016, fuel consumption of DDP and CHDP were not significantly different. For the two years, on average, the CHDP system used $14.45 \%$ less fuel and NT 79.65\% less fuel compared to the DDP. These results agree with the findings of [51] where the establishment of a wheat crop required up to seven times more volume of fuel compared with direct planting.

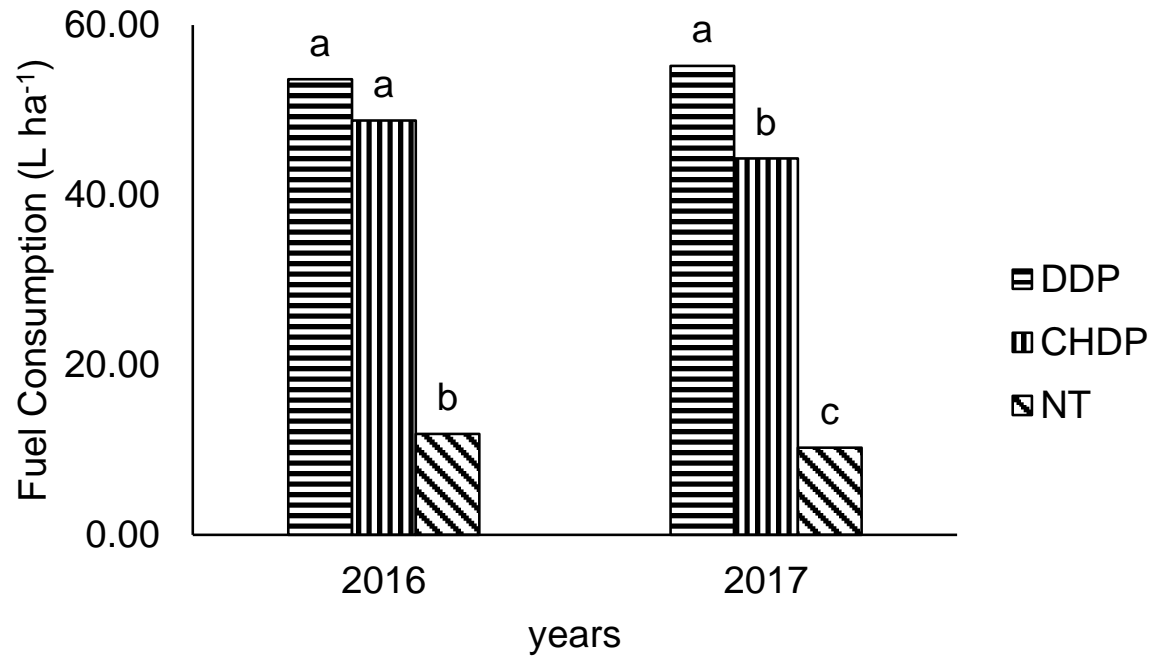

Figure 4. Fuel consumption per area for each tillage system; different letters in columns in the same year are significantly different (Tukey, $\alpha \leq 0.05$ ). 


\subsection{Overall Efficiency in the Use of Energy from the Fuel}

Figure 5 presents the percentage of the overall efficiency in the use of energy from the diesel fuel. For this study we used $38.597 \mathrm{MJ} \mathrm{L}^{-1}$, which is the higher heating value of a liter of diesel according to The American Society for Testing and Materials (ASTM) D975 [52].

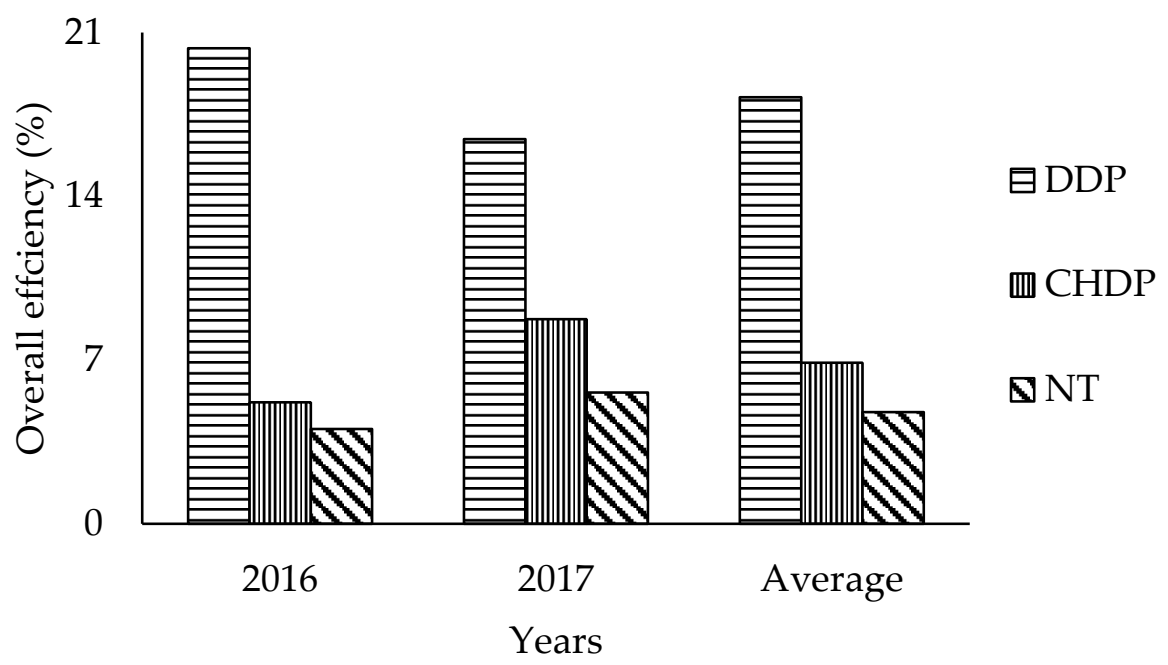

Figure 5. Overall efficiency in the use of energy from fuel by the tillage systems.

The overall efficiency in the use of energy from the fuel was calculated by dividing the net energy used per area by the total energy available in the volume of fuel used per area. This is calculated for each tillage system. The overall energy efficiency includes the load matching of the tractor and implement. A tractor-implement combination having an overall energy efficiency below $10 \%$ indicates poor load matching or/and low tractive efficiency, while a value above $20 \%$ indicates a good load match or/and high tractive efficiency [53]

Average efficiency in the use of energy by the tillage systems was quite low. For DDP resulted in $18.23 \%$, for CHDP $6.88 \%$, and $4.77 \%$ for NT. Similar results were found in other studies; the overall efficiency of energy use was in a range from $11 \%$ to $20.08 \%$ for different tillage implements [54,55].

Considering the total energy available in the fuel that was consumed per hectare; the overall efficiency indicates the percentage that is being used as net energy per hectare in the sequence of tillage operations for each system. Energy that is not used for the tillage operations is used to move the tractor, other losses are by heat, friction, transmission, and slippage, etc.

The low efficiency in the use of energy available from the fuel indicates an inadequate combination of tractor-implement for CHDP and NT. The equipment used was typical of the production methods used in our area, where the farmers normally only own one tractor, which they use for all their operations. The rated power is based on the demand of the disc plowing, which is the heaviest operation. For this reason, the power of the tractors used for the local conventional tillage is underutilized, because of the relatively light tillage operations of CHDP and NT. So, account should be taken of all the factors involved to increase, in the future, the efficiency in the use of energy in the tillage operations that demand less power. This could be achieved using lighter tractors, increasing the working width by using bigger implements, or increasing the working speed.

From the results of our study, conservation tillage (CHDP and NT) reduce the use of total energy for soil preparation compared to DDP significantly. But it is important that the amount of energy that corresponds to each system and operation is used with efficiency. According to the characteristics of the tractors in the region, attention has to be paid to a good match between power source-implement to achieve a good load matching and tractive efficiency and increase the overall efficiency. 


\subsection{Effect of Tillage on Bulk Density and Porosity of the Soil}

The use and cost of energy in the tillage systems is important, but a positive effect on soil properties for good crop development is the final goal of tillage. As an indicator of this effect, soil bulk density (Bd) was measured and soil porosity (Sp) calculated at the end of the summer cropping season in the tillage treatments in 2013 and after three years in 2016. This was done to look at the effects in the short term of the tillage systems on these soil physical variables. In Figure 6, it can be observed that the bulk density in 2013 was significantly lower only in the surface layer in the CHDP treatment compared to NT and DDP. For the deeper layers, there were no significant differences between treatments.

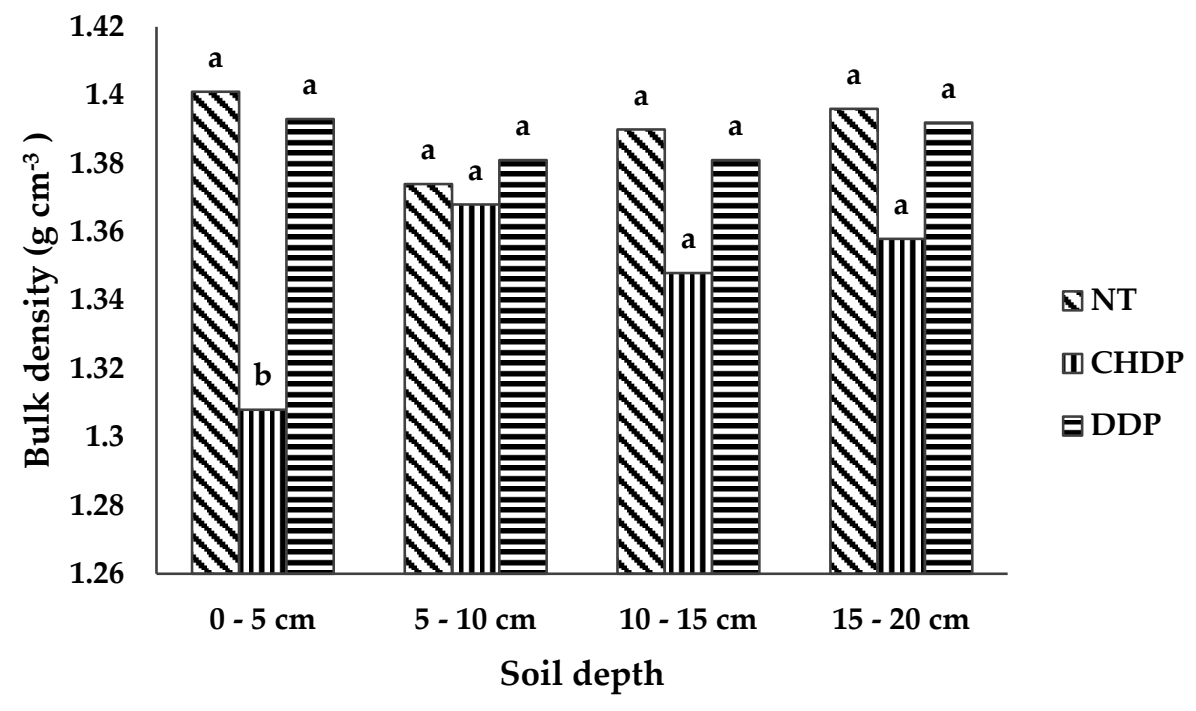

Figure 6. Bulk density in the soil profile at intervals of $5 \mathrm{~cm}$ at the beginning of the experiment in 2013. Mean values with the same letter in the same depth interval are not significantly different (Tukey, $\alpha \leq 0.05)$.

Total porosity depends on the value of Bd; it can be observed in Figure 7 that at the beginning of the experiment, total porosity was very similar for the treatments. The exception was the porosity in CHDP at the top layer that was significantly higher than DDP and NT.

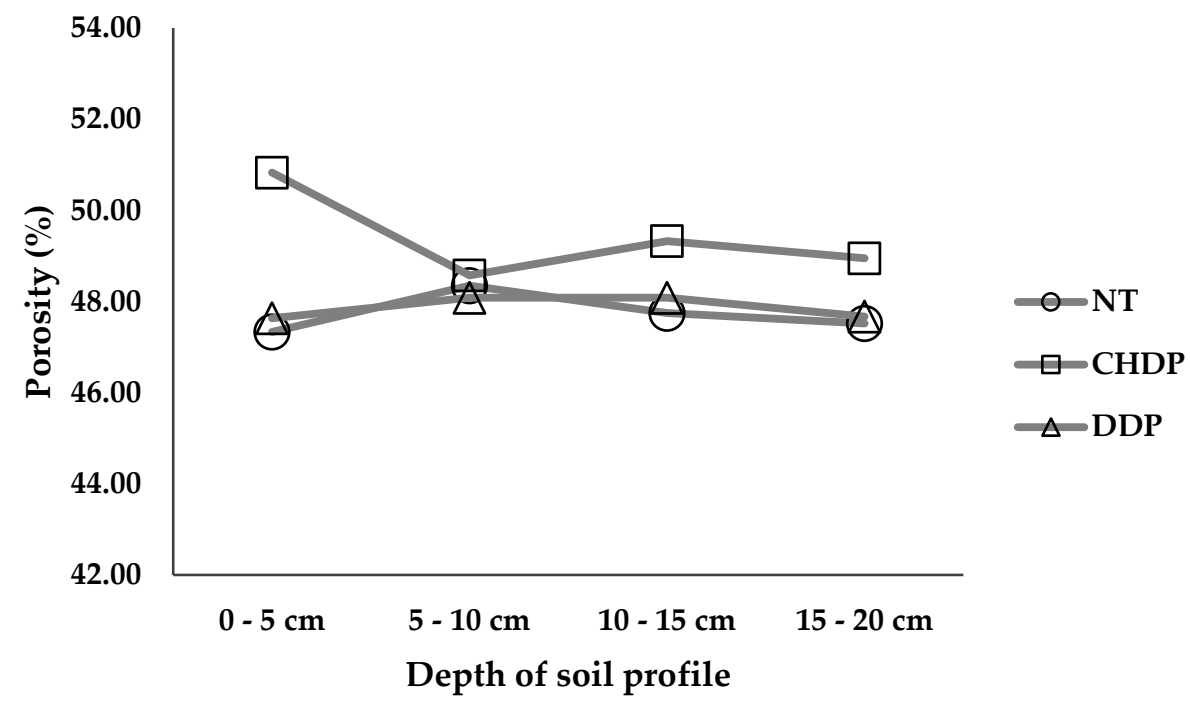

Figure 7. Total porosity in the soil profile at intervals of $5 \mathrm{~cm}$ at the beginning of the experiment in 2013.

After three years, the Bd decreased for the NT at all depth intervals and increased for the CHDP. The values of the Bd in the DDP decreased in the surface layer and the bottom layer and increased in 
the middle layers compared with the values of 2013 (Figure 8). The values for NT at all depths are significantly lower compared to CHDP and DDP.

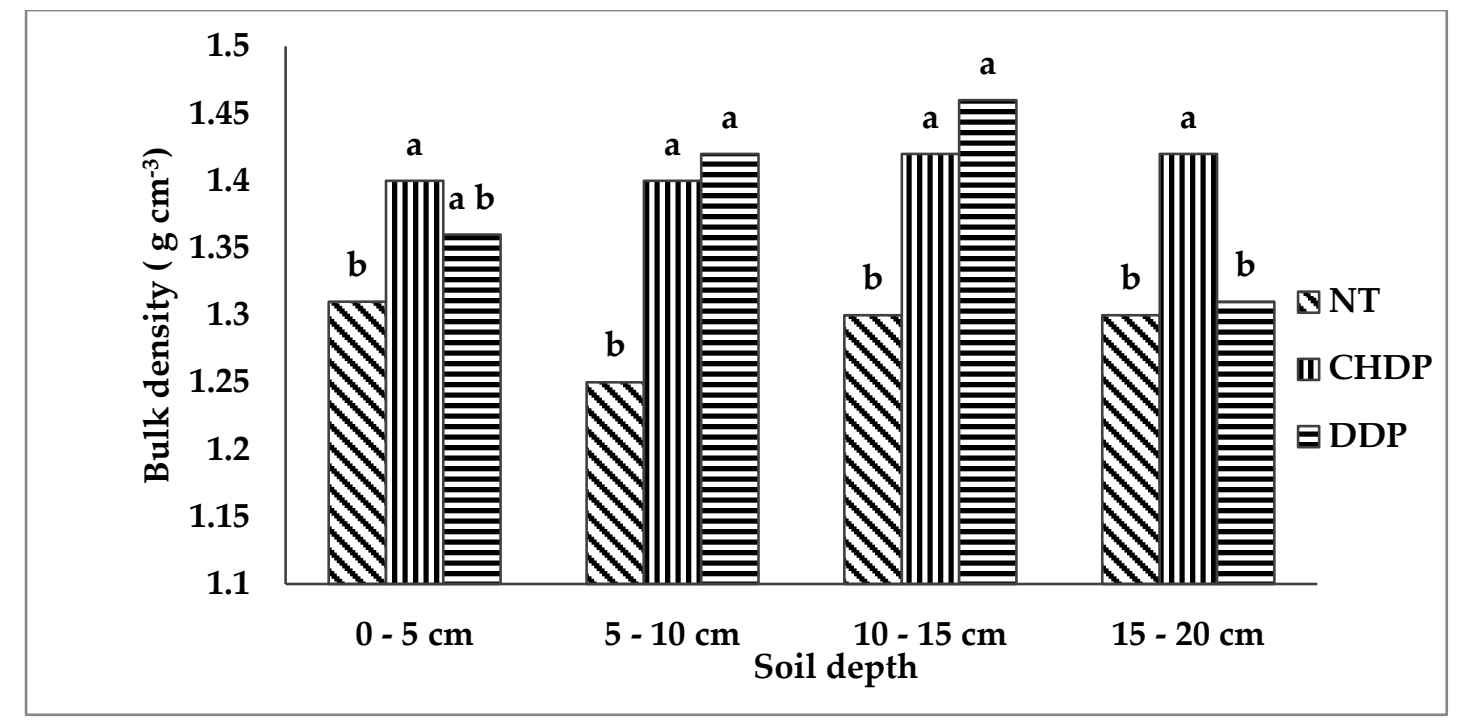

Figure 8. Bulk density in the soil profile at intervals of $5 \mathrm{~cm}$ after three years of the tillage treatments in 2016. Means values with the same letter in the same depth interval are not significantly different (Tukey, $\alpha \leq 0.05$ ).

Bulk density is an indicator of soil quality, and is often used for evaluating tillage effects [56]. If the density decreases (Figure 8), then the porosity increases (Figure 9), and the soil has more capacity for infiltration and storage of water, thus, improving its availability for the plants. [57]. After three years, the no-till treatment had the lowest bulk density and provided the highest total porosity (Figure 9).

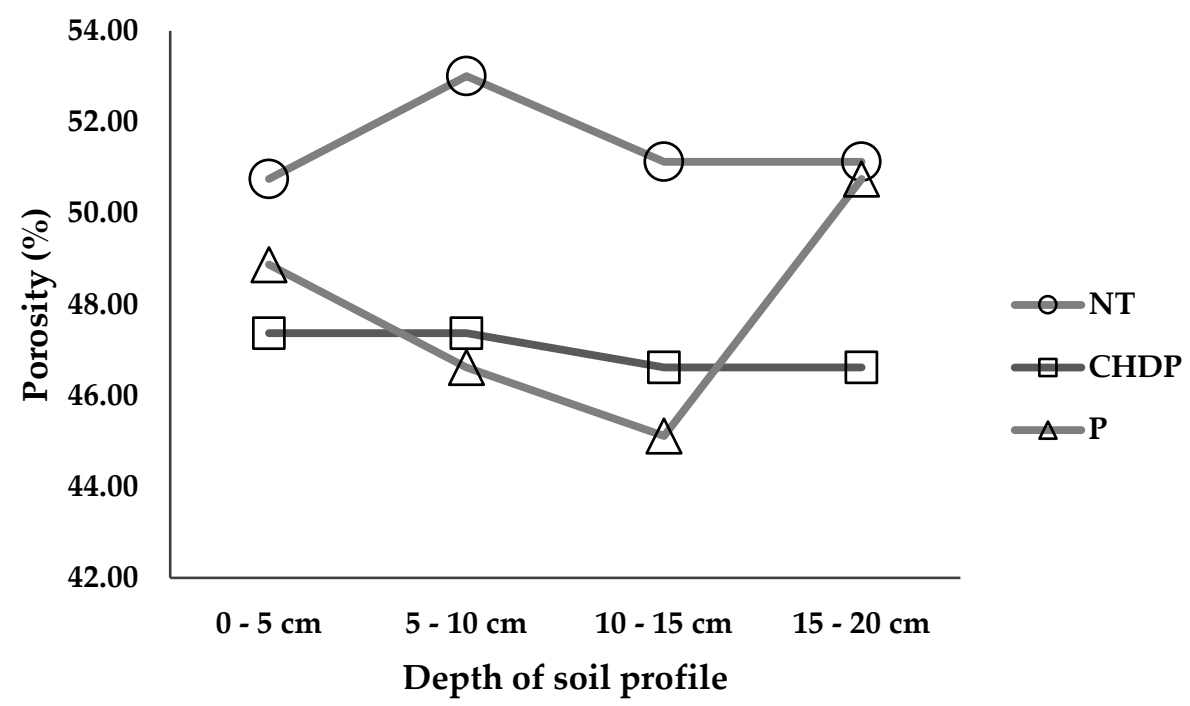

Figure 9. Soil porosity at intervals of $5 \mathrm{~cm}$ after three years of the tillage treatments in 2016 .

In similar studies, the results of the changes in the soil bulk density are contradictory. There are experiments in which there are higher increases with time of bulk density values under conventional compared with conservation tillage [58]. But other studies report that the no-till treatment had the highest bulk density and provided the lowest total porosity [59].

Other result shows that in the short term (after two years) direct planting treatment in clay soil in humid climate had a better physical condition and root distribution index than conventional tillage [60]. 
Another study, in a humid subtropical area of Mexico, showed that bulk density was significantly higher after three years with no tillage compared with conventional tillage [61].

Contrasting effects of soil management experiments in bulk density are common. Effects are related to the management of the machinery (weight of implements, number of passes) and to the soil water content at the moment of performing the tillage operation. [62]. From the point of machinery management, it is possible that in our experiment, the systems that have more tillage operations (DDP and (HDP), increased the soil bulk density compared to NT that has only one operation.

\subsection{Effect of Tillage on the Dry Matter Yield of Maize}

The reduction of tillage operations and, thus, the cost of energy should not affect the yields of crops. For the adoption of conservation tillage, the farmer must have a good balance in the cost-benefit of the production system. To study the effect of tillage systems on the dry matter, the yield of maize was measured for the seasons 2013 and 2014. There were no significant differences between treatments as shown in Figure 10. However, in both years the yield of NT was $16.2 \%$ and $12.8 \%$ higher than DDP. The yield CHDP was $10.8 \%$ and $11.5 \%$ higher than DDP.

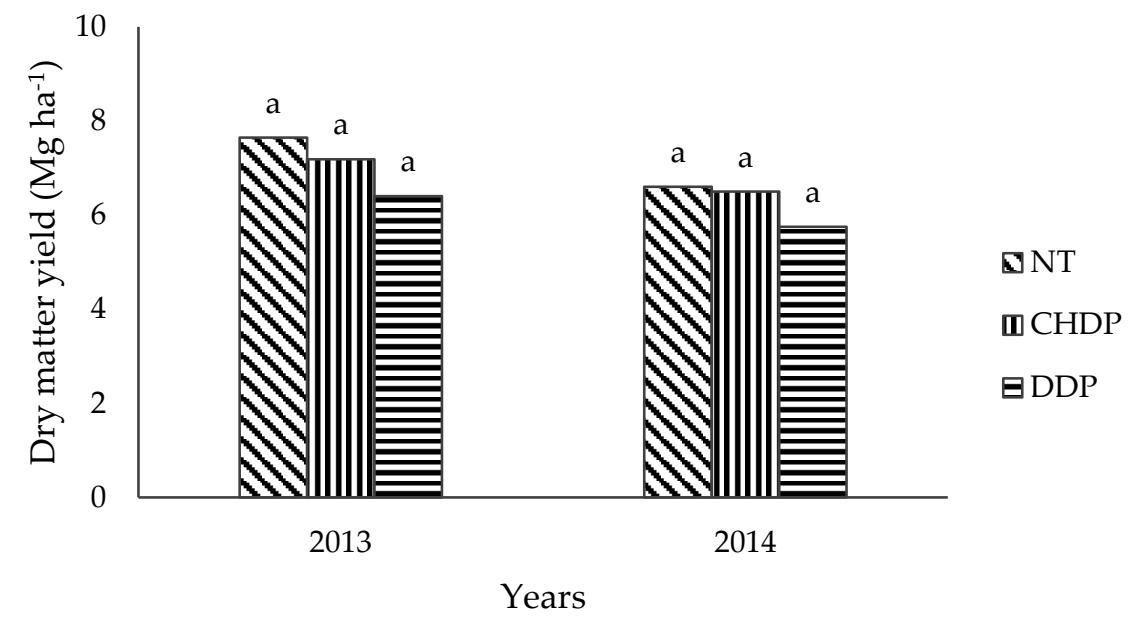

Figure 10. Dry matter yield of maize for the three tillage systems in the seasons 2013 and 2014. Mean values with the same letter in the same year are not significantly different (Tukey, $\alpha \leq 0.05$ ).

Our study agrees with other similar studies [63] where maize yield was higher with conservation tillage practices in an area of limited rainfall. This might be attributed to moisture conservation in low rainfall areas under conservation agriculture.

No-till practices enhance water use efficiency when residues are retained, this is why conservation tillage performs better than conventional tillage under limited water conditions [10]. Conservation tillage can increase crop productivity in dry climates. Hence, it may become an important climate-change adaptation strategy for these regions of the world. [64,65].

\section{Conclusions}

The conservation tillage systems CHDP and NT demand less specific energy per area compared to the conventional system DDP. It is possible to save 64\% in energy with CHDP and $93 \%$ in energy with P compared with the energy expenditure of DDP.

For each of the tillage systems, the planting operation applied the highest specific energy to the soil mass. This is because it moves less volume of soil.

The sequence of tillage operations in the DDP system had the highest fuel consumption per worked area compared to the other systems. On average, the CHDP system can save $14.45 \%$ fuel, and the NT can save $79.65 \%$ of fuel, compared with the DDP system. 
The overall efficiency in the use of energy was better in DDP compared to CHDP and NT. Attention has to be paid to a good match between tractor-implement to achieve a good load matching and tractive efficiency in conservation systems.

The NT system significantly decreases the values of the soil bulk density after three years, compared to DDP and CHDP. P increases the total porosity, leaving the soil in better condition for intake and storage of water.

NT and CHDP had a higher yield than DDP in dry matter yield of maize, although not of statistical significance.

In the semiarid areas of Mexico, NT and CHDP are a good option to decrease the use of energy for soil preparation. NT also improved the physical condition of the soil.

Author Contributions: Conceptualization, M.C.-Z. and S.C.-M.; Methodology, M.C.-Z., S.C.-M., A.Z.-G., A.L.-V.; Software, A.L.-V.; Validation, A.Z.-G., A.L.-V. and M.C.-Z.; Formal Analysis, M.C.-Z.; Investigation, A.L.-V., M.C.-Z., S.C.-M.; Resources, A.Z.-G., M.M.-D.; Data Curation, M.C.-Z., A.L.-V.; Writing-Original Draft Preparation, M.C.-Z., A.L.-V.; Writing-Review and Editing, M.C.-Z., M.M.-D.

Funding: This research received no external funding, internal funds were provided by Universidad Autonoma Agraria Antonio Narro (UAAAN).

Acknowledgments: The authors acknowledge the technical support from the staff of Agricultural Machinery Department of Universidad Autonoma Agraria Antonio Narro and to David Mann for the revision of the manuscript.

Conflicts of Interest: The authors declare no conflict of interest. The internal funder UAAAN had no role in the design of the study; in the collection, analyses, or interpretation of data; in the writing of the manuscript, and in the decision to publish the results.

\section{References}

1. Canakci, M.; Topakci, M.; Akinci, I.; Özmerzi, A. Energy use pattern of some field crops and vegetable production: Case study for Antalya Region, Turkey. Convers. Manag. 2005, 46, 655-666. [CrossRef]

2. Chamsing, A.; Salokhe, V.; Singh, G. Energy Consumption Analysis for Selected Crops in Different Regions of Thailand". Agric. Eng Int: CIGR J. 2006, 8, 1-18.

3. Tabatabaeefar, A.; Emamzadeh, H.; Varnamkhasti, M.; Rahimizadeh, R.; Karimi, M. Comparison of energy of tillage systems in wheat production. Energy 2009, 34, 41-45. [CrossRef]

4. Fischer, R.; Connor, D. Issues for cropping and agricultural science in the next 20 years. Crop. Res. 2018, 222, 121-142. [CrossRef]

5. Mileusnić, Z.; Petrović, D.; Đević, M. Comparison of tillage systems according to fuel consumption. Energy 2010, 35, 221-228. [CrossRef]

6. Castellini, M.; Ventrella, D. Impact of conventional and minimum tillage on soil hydraulic conductivity in typical cropping system in Southern Italy. Soil Res. 2012, 124, 47-56. [CrossRef]

7. Campos-Magaña, S.G.; Cadena-Zapata, M.; Ramírez-Fuentes, G.; Pacheco-López, J.L.; Reynolds-Chavez, M.A.; Valezuela-Garcia, J.R. An experimental determination of the specific soil resistance of a sandy loam soil using vertical soil tillage in the Northeast of Mexico. Agricul. Mech. Asia Africa Latin Am. 2015, 46, 53-57.

8. Reicosky, D.C. Conservation tillage is not conservation agriculture. J. Soil Conserv. 2015, 70, 103-108. [CrossRef]

9. Derpsch, R. Conservation Tillage, No-Tillage and Related Technologies. In Conservation Agriculture; Springer Nature: Basingstoke, UK, 2003; pp. 181-190.

10. Pittelkow, C.M.; Linquist, B.A.; Lundy, M.E.; Liang, X.; Van Groenigen, K.J.; Lee, J.; Van Gestel, N.; Six, J.; Venterea, R.T.; Van Kessel, C. When does no-till yield more? A global meta-analysis. Crop. Res. 2015, 183, 156-168. [CrossRef]

11. Kojima, M. Drawing a Roadmap for Oil Pricing Reform. In Household Savings in Central Eastern and Southeastern Europe: How Do Poorer Households Save? The World Bank: Washington, DC, USA, 2013.

12. Rodríguez, R.G. La simple aritmética de la nueva política de precios de las gasolinas y el diesel. Economía Informa 2017, 404, 40-62. [CrossRef]

13. Esengun, K.; Erdal, G.; Gündüz, O.; Erdal, H. An economic analysis and energy use in stake-tomato production in Tokat province of Turkey. Renew. Energy 2007, 32, 1873-1881. [CrossRef] 
14. Ghorbani, R.; Mondani, F.; Amirmoradi, S.; Feizi, H.; Khorramdel, S.; Teimouri, M.; Sanjani, S.; Anvarkhah, S.; Aghel, H. A case study of energy use and economical analysis of irrigated and dryland wheat production systems. Appl. Energy 2011, 88, 283-288. [CrossRef]

15. Steiner, K.G. Conserving Natural Resources and Enhancing Food Security by Adopting No Tillage; Deutsche Gesellschaft für Technische Zusammenarbeit (GTZ) GmbH: Rossdorf, Germany, 1998.

16. Erdal, G.; Esengun, K.; Erdal, H.; Gündüz, O. Energy use and economical analysis of sugar beet production in Tokat province of Turkey. Energy 2007, 32, 35-41. [CrossRef]

17. Pelletier, N.; Audsley, E.; Brodt, S.; Garnett, T.; Henriksson, P.; Kendall, A.; Kramer, K.J.; Murphy, D.; Nemecek, T.; Troell, M. Energy Intensity of Agriculture and Food Systems. Annu. Rev. Environ. Resour. 2011, 36, 223-246. [CrossRef]

18. Sharma, P.; Abrol, V.; Sharma, R. Impact of tillage and mulch management on economics, energy requirement and crop performance in maize-wheat rotation in rainfed subhumid inceptisols, India. Eur. J. Agron. 2011, 34, 46-51. [CrossRef]

19. Rathke, G.-W.; Wienhold, B.; Wilhelm, W.; Diepenbrock, W. Tillage and rotation effect on corn-soybean energy balances in eastern Nebraska. Soil Res. 2007, 97, 60-70. [CrossRef]

20. Jokiniemi, T.; Mikkola, H.; Rossner, H.; Talgre, L.; Lauringson, E.; Hovi, M.; Ahokas, J. Energy savings in plant production. Agron. Res. Biosyst. Eng. 2012, 1, 85-96.

21. Gonzalez-De-Soto, M.; Emmi, L.; García, I.; Gonzalez-De-Santos, P. Reducing fuel consumption in weed and pest control using robotic tractors. Comput. Electron. Agric. 2015, 114, 96-113. [CrossRef]

22. Lee, J.W.; Kim, J.S.; Kim, K.U. Computer simulations to maximise fuel efficiency and work performance of agricultural tractors in rotovating and ploughing operations. Biosyst. Eng. 2016, 142, 1-11. [CrossRef]

23. Moreno, M.; Lacasta, C.; Meco, R.; Moreno, C. Rainfed crop energy balance of different farming systems and crop rotations in a semi-arid environment: Results of a long-term trial. Soil Res. 2011, 114, 18-27. [CrossRef]

24. Wolf, D.; Hadas, A. Determining efficiencies of various moldboard ploughs in fragmenting and tilling air-dry soils. Soil Res. 1987, 10, 181-190. [CrossRef]

25. SIAP. Servicio de Informacion Agroalimentaria y Pesquera. Infografias agroalimentarias. Available online: https://nube.siap.gob.mx/gobmx_publicaciones_siap/pag/2018/Infografias-2018 (accessed on 30 March 2019).

26. Baumhardt, R.L.; Salinas-Garcia, J. Dryland Agriculture in Mexico and the U.S. Southern Great Plains. In Dryland Agriculture, 2nd ed.; American Society of Agronomy, Crop Science Society of America, Soil Science Society of America: Madison, WI, USA, 2006.

27. Fuentes, M.; Govaerts, B.; De León, F.; Hidalgo, C.; Dendooven, L.; Sayre, K.D.; Etchevers, J. Fourteen years of applying zero and conventional tillage, crop rotation and residue management systems and its effect on physical and chemical soil quality. Eur. J. Agron. 2009, 30, 228-237. [CrossRef]

28. Vakali, C.; Zaller, J.G.; Köpke, U. Reduced tillage effects on soil properties and growth of cereals and associated weeds under organic farming. Soil Res. 2011, 111, 133-141. [CrossRef]

29. Singh, P.N.; Munk, D.S.; Wroble, J.F.; Hogan, P.; Roy, R.; Hanson, B.R.; Mitchell, J.P.; Wallender, W.W.; Horwath, W.R. No-tillage and high-residue practices reduce soil water evaporation. Calif. Agric. 2012, 66, 55-61.

30. Alvarez, R.; Steinbach, H. A review of the effects of tillage systems on some soil physical properties, water content, nitrate availability and crops yield in the Argentine Pampas. Soil Res. 2009, 104, 1-15. [CrossRef]

31. Alegre, J.; Cassel, D.; Amézquita, E. Tillage systems and soil properties in Latin America. Soil Res. 1991, 20, 147-163. [CrossRef]

32. Salem, H.M.; Valero, C.; Muñoz, M.A.; Gil Rodríguez, M.; Silva, L.L. Short-term effects of four tillage practices on soil physical properties, soil water potential, and maize yield. Geoderma 2015, 237, 60-70. [CrossRef]

33. Bertocco, M.; Basso, B.; Sartori, L.; Martin, E. Evaluating energy efficiency of site-specific tillage in maize in NE Italy. Bioresour. Technol. 2008, 99, 6957-6965. [CrossRef]

34. Campos Magaña, S.G.; Reynolds Chávez, M.A.; Cadena Zapata, M.; López López, J.A.; Cuervo Piña, N.; Ramírez Fuentes, G. Desarrollo de un sistema integral de medición de fuerzas para la evaluación de implementos de labranza. Terra Latinoamericana 2015, 33, 139-149.

35. Bowers, C.G., Jr. Southeastern tillage energy data and recommended reporting. Trans. ASAE 1985, 28, 731-737. [CrossRef]

36. Campbell, D. Determination and Use of Soil Bulk Density in Relation to Soil Compaction. Dev. Agric. Eng. 1994, 11, 113-139. 
37. Flint, A.L.; Flint, L.E. Particle density. In Methods of Soil Analysis; Dane, J.H., Topp, G.C., Eds.; Part 4. Physical Methods; Soil Science Society of America: Madison, WI, USA, 2002; pp. 229-240.

38. Demuner-Molina, G.; Cadena-Zapata, M.; Campos-Magaña, S.G.; Zermeño-González, A.; Sánchez-Pérez, F.J. Efecto de labranza y mejoradores de suelo en humedad y desarrollo radicular. Tecnología y Ciencias del Agua 2014, 5, 123-130.

39. ASABE Standards. D497.7: MAR2011 (R2015) Agricultural Machinery Management Data. Available online: https://webstore.ansi.org/standards/asabe/asaed497mar2011r2015 (accessed on 29 March 2019).

40. McLaughlin, N.B.; Drury, C.F.; Reynolds, W.D.; Yang, X.M.; Li, Y.X.; Welacky, T.W.; Stewart, G. Energy Inputs for Conservation and Conventional Primary Tillage Implements in a Clay Loam Soil. Trans. ASABE 2008, 51, 1153-1163. [CrossRef]

41. Alhajj Ali, S.; Tedone, L.; De Mastro, G. A comparison of the energy consumption of rainfed durum wheat under diferent management scenarios in southern Italy. Energy 2013, 61, 308-318. [CrossRef]

42. Ranjbarian, S.; Askari, M.; Jannatkhah, J. Performance of tractor and tillage implements in clay soil. J. Saudi Soc. Agric. Sci. 2017, 16, 154-162. [CrossRef]

43. Okoko, P.; Ajav, E.A.; Olosunde, W.A. Draft and power requirements for some tillage implements operating in clay loam soil. Agric. Eng. Int. CIGR J. 2018, 20, 95-102.

44. Moitzi, G.; Szalay, T.; Schüller, M.; Wagentristl, H.; Refenner, K.; Weingartmann, H.; Liebhard, P.; Boxberger, J.; Gronauer, A. Effects of tillage systems and mechanization on work time, fuel and energy consumption for cereal cropping in Austria. Agric. Eng. Int. CIGR J. 2013, 15, 94-101.

45. Hernanz, J.L.; Sánchez-Girón, V.; Navarrete, L.; Sánchez, M.J. Long-term (1983-2012) assessment of three tillage systems on the energy use efficiency, crop production and seeding emergence in a rain fed cereal monoculture in semiarid conditions in central Spain. Field Crops Res. 2014, 166, 26-37. [CrossRef]

46. Chen, G.; Baillie, C. Development of a framework and tool to asses on-farm energy uses of cotton production. Convers. Manag. 2009, 50, 1256-1263. [CrossRef]

47. Hamzei, J.; Seyyedi, M. Energy use and input-output costs for sunflower production in sole and intercropping with soybean under different tillage systems. Soil Res. 2016, 157, 73-82. [CrossRef]

48. Moitzi, G.; Wagentristl, H.; Refenner, K.; Weingartmann, H.; Piringer, G.; Boxberger, J.; Gronauer, A. Effects of working depth and wheel slip on fuel consumption of selected tillage implements. Agric. Eng. Int. CIGR J. 2014, 16, 182-190.

49. Hadas, A.; Wolf, D. Soil Aggregates and Clod Strength Dependence on Size, Cultivation, and Stress Load Rates1. Soil Sci. Soc. Am. J. 1984, 48, 1157-1164. [CrossRef]

50. Šarauskis, E.; Buragienè, S.; Masilionytė, L.; Romaneckas, K.; Avižienytė, D.; Sakalauskas, A. Energy balance, costs and CO2 analysis of tillage technologies in maize cultivation. Energy 2014, 69, 227-235. [CrossRef]

51. Yalcin, H.; Cakir, E. Tillage effects and energy efficiencies of subsoiling and direct seeding in light soil on yield of second crop corn for silage in Western Turkey. Soil Res. 2006, 90, 250-255. [CrossRef]

52. Alleman, T.L.; McCormick, R.L.; Christensen, E.D.; Fioroni, G.; Moriarty, K.; Yanowitz, J. Biodiesel Handling and Use Guide, 4th ed.; U.S. Department of Energy: Washington, DC, USA, 2016.

53. Kheiralla, A.; Yahya, A.; Zohadie, M.; Ishak, W. Modelling of power and energy requirements for tillage implements operating in Serdang sandy clay loam, Malaysia. Soil Res. 2004, 78, 21-34. [CrossRef]

54. Celik, A.; Gokalp Boydas, M.; Turgut, N. Comparison of the Energy Requirements of an Experimental Plow, a Moldboard Plow and a Disk Plow. Philipp. Agric. Sci. 2007, 90, 173-178.

55. Khadr, K.A.A. Effect of some primary tillage implement on soil pulverization and specific energy. Misr. J. Agric. Eng. 2008, 25, 731-745.

56. Logsdon, S.D.; Karlen, D.L. Bulk density as a soil quality indicator during conversion to no-tillage. Soil Res. 2004, 78, 143-149. [CrossRef]

57. Reynolds, W.; Drury, C.; Tan, C.; Fox, C.; Yang, X. Use of indicators and pore volume-function characteristics to quantify soil physical quality. Geoderma 2009, 152, 252-263. [CrossRef]

58. Alletto, L.; Coquet, Y. Temporal and spatial variability of soil bulk density and near-saturated hydraulic conductivity under two contrasted tillage management systems. Geoderma 2009, 152, 85-94. [CrossRef]

59. Gozubuyuk, Z.; Sahin, U.; Ozturk, I.; Celik, A.; Adiguzel, M.C. Tillage effects on certain physical and hydraulic properties of a loamy soil under a crop rotation in a semi-arid region with a cool climate. CATENA 2014, 118, 195-205. [CrossRef] 
60. Chen, Y.; Cavers, C.; Tessier, S.; Monoro, F.; Lobb, D. Short-term effects on soil cone index and plant development in a poorly drained, heavy clay soil. Soil Tillage Res. 2005, 161-171. [CrossRef]

61. Monneveux, P.; Quillerou, E.; Sanchez, C.; Lopez-Cesati, J. Effect of Zero Tillage and Residues Conservation on Continuous Maize Cropping in a Subtropical Environment (Mexico). Plant Soil 2006, 279, 95-105. [CrossRef]

62. Martínez, E.; Fuentes, J.-P.; Silva, P.; Valle, S.; Acevedo, E. Soil physical properties and wheat root growth as affected by no-tillage and conventional tillage systems in a Mediterranean environment of Chile. Soil Res. 2008, 99, 232-244. [CrossRef]

63. Rusinamhodzi, L.; Corbeels, M.; Van Wijk, M.T.; Rufino, M.; Nyamangara, J.; Giller, K.E. A meta-analysis of long-term effects of conservation agriculture on maize grain yield under rain-fed conditions. Agron. Sustain. Dev. 2011, 31, 657-673. [CrossRef]

64. Stevenson, J.R.; Serraj, R.; Cassman, K.G. Evaluating conservation agriculture for small-scale farmers in Sub-Saharan Africa and South Asia. Agric. Ecosyst. Environ. 2014, 187, 1-10. [CrossRef]

65. Pittelkow, C.M.; Liang, X.; Linquist, B.A.; van Groenigen, K.J.; Lee, J.; Lundy, M.E.; van Gestel, N.; Six, J.; Rodney, T.; Venterea, R.T.; et al. Productivity limits and potentials of the principles of conservation agriculture. Nature 2015, 517, 365-368. [CrossRef]

(C) 2019 by the authors. Licensee MDPI, Basel, Switzerland. This article is an open access article distributed under the terms and conditions of the Creative Commons Attribution (CC BY) license (http://creativecommons.org/licenses/by/4.0/). 